\title{
GOVERNANCE FOR E-BUSINESS KNOWLEDGE MANAGEMENT SYSTEMS
}

\author{
RODGER JAMIESON \\ SEAR - Security E-Business Assurance Research Group, School of Information Systems \\ Technology and Management, University of New South Wales, Australia
}

\begin{abstract}
When introducing E-Business Knowledge Management (EBKM) systems into organisations, management should carefully assess the risks and threats to these systems to ensure that they are well-secured and controllable and do not leave the organisation exposed to unwanted litigation or adverse publicity. This paper addresses this concern by raising IT governance risk issues and suggesting security and control features that may be put in place to protect both the EBKM systems and the organisation. The paper also addresses research in progress in this area, namely, to gather details of risks and controls via a survey and to undertake a case study of an organisation with a mature EBKM strategy which has considered the risks, security and controls for KM.
\end{abstract}

\section{INTRODUCTION}

E-business systems are increasingly being deployed throughout organisations. Knowledge is an extremely valuable resource which allows organizations to share knowledge amongst its employees and customers and often forms part of e-business systems. Knowledge management (KM) is a "...multi-disciplined approach to achieving organisational objectives by making the best use of knowledge." (Standards Australia HB275-2001). KM is also defined as "...a broad collection of organisational practices and approaches to generating, capturing, disseminating know-how and other content relevant to the organisation's business". (Stephen Denning, World Bank 2001).

The original version of this chapter was revised: The copyright line was incorrect. This has been corrected. The Erratum to this chapter is available at DOI: 10.1007/978-0-387-35692-1_36 
Organizations operate in a fragile world and are subject to natural disasters, terrorism, cyber terrorism, e-crime, and a range of other threats to its information and knowledge resources and systems (CSI, 2001). Unfortunately there are risks and consequences associated with knowledge management systems, which if not adequately controlled and audited, and may breach privacy concerns and legislation. In order to protect knowledge assets from these threats, organizations should put in place appropriate security and control measures to counter these threats. The management process involved in considering threats and appropriate security measures is called risk management. This paper addresses these issues and provides a framework and guidelines for management to provide assurance over their EBKM systems.

The paper will first consider the senior management viewpoint from a risk management perspective. The risks security and control mechanisms involved in EBKM will be outlined using the knowledge management framework provided by Standards Australia. The paper will also consider privacy issues related to the capture and use of knowledge in an organization's knowledge management systems. Finally the paper will address the research in progress to gather details of risks and controls via a survey and to undertake a case study of an organisation with a mature KM strategy which has considered the risks security and controls for EBKM.

\section{RESEARCH OBJECTIVES}

The objectives of this research are to:

- understand risk management as it applies to knowledge management;

- identify risks associated with knowledge management;

- identify security and controls that may assist in preventing, detecting or correcting the risks associated with knowledge management; and

- understand the implications of privacy legislation to knowledge management systems and repositories.

In order to achieve these objectives the research will undertake a survey of knowledge management within organisations from a risk management perspective. In addition, detailed case studies will be undertaken with organisations having a mature $\mathrm{KM}$ environment in order to understand their methods of controlling risks within the $\mathrm{KM}$ environment. 


\section{THEORETICAL BACKGROUND - RISK MANAGEMENT}

Strategically, it is important to ensure that knowledge management is an issue that is being considered by the corporate and IT governance committees. Knowledge management governance should ensure that the objectives of knowledge management are part of the strategic planning process and both the corporate and IT strategic planning levels. When considering the key issues of EBKM security, controls, and audit assurance of $\mathrm{KM}$ infrastructure and systems, it is important that a risk management strategy be considered and that the internal and external IT auditors and security personnel be consulted in this process. These personnel will be able to provide advice on identifying risks and abuses within EBKM systems, and helped to place appropriate security and controls to help mitigate these risks and threats. Guidance in this area may also be found from the IT Governance Institute in their document on Information Security Governance (IT Governance Institute, 2001).

Before discussing risk management in detail we will consider the different framework and models of knowledge management and then investigate whether risk management is considered as part of these frameworks. Holsapple and Singh (2000) consider that there is a need for $\mathrm{KM}$ frameworks that will provide researchers with a holistic view, common ground, consistent terminology and units of analysis across a variety of research settings. Earl (2001) argues that practitioners need frameworks so that they can understand both $\mathrm{KM}$ initiatives and investments that are possible and identify those that make sense and are feasible. A review of the literature revealed a number of $\mathrm{KM}$ models or frameworks for systems development. These include knowledge management models in the KM review by McAdam and McCreedy (1999) distinguishing between knowledge categories models, intellectual capital models and socially constructed models of $\mathrm{KM}$. Another taxonomy of $\mathrm{KM}$ strategies is provided by Earl (2001) who identifies three schools - technocratic, economic and behavioural, which are very similar is essence to the categorisation of McAdam and McCreedy. Alvi and Leidner (2001) classify six knowledge perspectives and ten knowledge types or categories and then proceed to discuss the knowledge processes of knowledge creation, storage and retrieval, transfer, application and the enabling role of IT is KM activities. Their contribution is to focus on knowledge processes and enablers and considers the concept of a knowledge life cycle. Handzic and Hasan (2002) provide a further review of knowledge frameworks by adapting the work of Handzic (2001) which extends the intial work by Handzic and Jamieson 
(2001). They propose an integrated KM framework (refer figure covering organisational environment, technological infrastructure, knowledge processes, organisational knowledge and knowledge measurement.

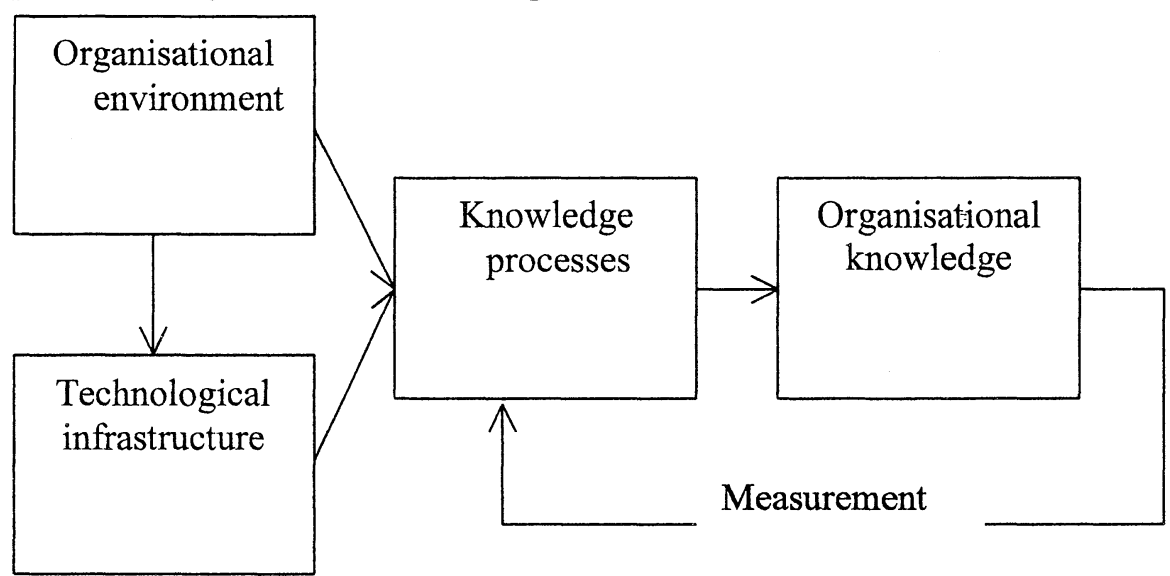

Figure 1. An Integrated KM Framework (Handzic, 2002)

Various authors Nonaka (1991), Ruggles (1997), Angus et al. (1998), Jackson (1999), Wensley (2000), Tyndale (2001), Robinson et al. (2001), have also suggested frameworks or models for knowledge development. These are compared in Table 1. The problem with all of these frameworks is that they do not explicitly discuss risk management as an important component of the $\mathrm{KM}$ development process. 


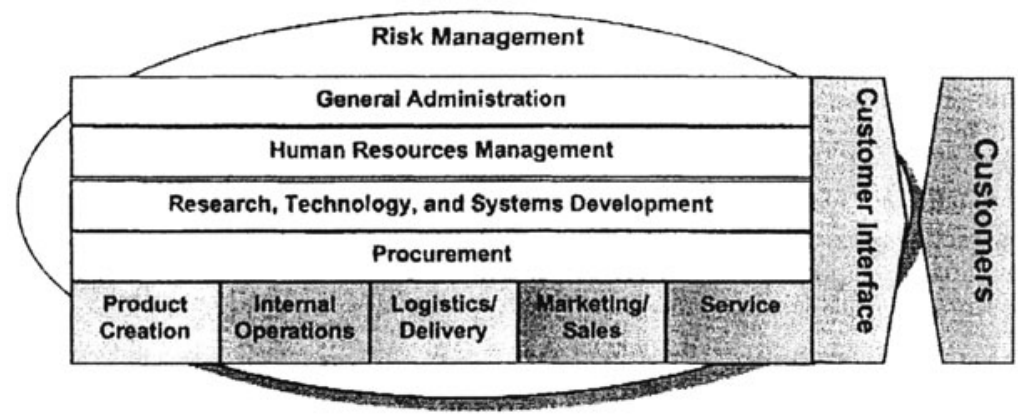

Figure 2. Risk Inherent in the Banking Industry using Porter's (1995) Value Chain

Source Ribiere, V. \& C Chou (2001)

\begin{tabular}{|c|c|c|c|c|c|}
\hline Phase & One & Two & Three & Four & Five \\
\hline $\begin{array}{l}\text { Nonaka's } \\
\text { KM } \\
\text { Model } \\
(1991) \\
\end{array}$ & Socialisation & Externalisation & Combination & Internalisation & \\
\hline $\begin{array}{l}\text { Ruggles } \\
\text { (1997) }\end{array}$ & $\begin{array}{l}\text { Generation } \\
\text { Acquisition } \\
\text { Synthesis } \\
\text { Creation } \\
\text { Fusion } \\
\text { Adaption }\end{array}$ & $\begin{array}{l}\text { Codification } \\
\text { Auditing } \\
\text { Categorisation }\end{array}$ & $\begin{array}{l}\text { Transfer } \\
\text { Face-to-Face } \\
\text { Collaboration } \\
\text { Dissemination }\end{array}$ & & \\
\hline $\begin{array}{l}\text { Angus et } \\
\text { al. } \\
(1998)\end{array}$ & $\begin{array}{l}\text { Gathering } \\
\text { Pull } \\
\text { Searching } \\
\text { Data Entry }\end{array}$ & $\begin{array}{l}\text { Organising } \\
\text { Cataloguing } \\
\text { Filtering } \\
\text { Linking } \\
\text { Indexing }\end{array}$ & $\begin{array}{l}\text { Refining } \\
\text { Contextualising } \\
\text { Mining } \\
\text { Projecting } \\
\text { Compacting } \\
\text { Collaborating } \\
\end{array}$ & $\begin{array}{l}\text { Disseminating } \\
\text { Flow } \\
\text { Push } \\
\text { Sharing } \\
\text { Notify }\end{array}$ & \\
\hline $\begin{array}{l}\text { Jackson } \\
\text { (1999) }\end{array}$ & $\begin{array}{l}\text { Gathering } \\
\text { Pull } \\
\text { Searching } \\
\text { Data Entry / } \\
\text { OCR }\end{array}$ & $\begin{array}{l}\text { Storage } \\
\text { Filtering } \\
\text { Linking } \\
\text { Indexing }\end{array}$ & $\begin{array}{l}\text { Communicat'n } \\
\text { Sharing } \\
\text { Collaboration } \\
\text { Group } \\
\text { discussion }\end{array}$ & $\begin{array}{l}\text { Synthesis } \\
\text { Analysis } \\
\text { Creation } \\
\text { Contextua- } \\
\text { lisation }\end{array}$ & $\begin{array}{l}\text { Dissemination } \\
\text { Push } \\
\text { Publishing } \\
\text { Notification }\end{array}$ \\
\hline $\begin{array}{l}\text { Wensley } \\
(2000)\end{array}$ & $\begin{array}{l}\text { Generation } \\
\text { Communication } \\
\text { Culture } \\
\text { Barriers } \\
\end{array}$ & $\begin{array}{l}\text { Codification } \\
\text { Conceptual } \\
\text { analysis } \\
\text { Rules } \\
\end{array}$ & $\begin{array}{l}\text { Refinement } \\
\text { Rule deduction } \\
\text { Filtering } \\
\text { Classification } \\
\end{array}$ & $\begin{array}{l}\text { Transmission } \\
\text { Assimilation } \\
\text { Face-to-Face }\end{array}$ & \\
\hline $\begin{array}{l}\text { Tyndale } \\
2001\end{array}$ & $\begin{array}{l}\text { Creation } \\
\text { Capture } \\
\end{array}$ & $\begin{array}{l}\text { Organisation } \\
\text { Interpretation }\end{array}$ & $\begin{array}{l}\text { Distribution } \\
\text { Publishing } \\
\end{array}$ & $\begin{array}{l}\text { Application } \\
\text { Process }\end{array}$ & \\
\hline
\end{tabular}




\begin{tabular}{|c|c|c|c|c|c|}
\hline KDLCM & $\begin{array}{l}\text { Generation } \\
\text { Gathering } \\
\text { Absorption } \\
\text { Assimilation }\end{array}$ & $\begin{array}{l}\text { Filtering } \\
\text { Codification } \\
\text { Categorisation } \\
\text { Amalgation }\end{array}$ & $\begin{array}{l}\text { Face-to-Face } \\
\text { Dissemination } \\
\text { Transmission }\end{array}$ & $\begin{array}{l}\text { Change } \\
\text { Revise } \\
\text { Amendment } \\
\text { Review }\end{array}$ & \\
\hline $\begin{array}{l}\text { McGrath } \\
\text { \& Walsh } \\
(2001)\end{array}$ & Acquisition & $\begin{array}{l}\text { Codification / } \\
\text { Storage }\end{array}$ & $\begin{array}{l}\text { Dissemination / } \\
\text { Fabrication }\end{array}$ & $\begin{array}{l}\text { Application / } \\
\text { Use }\end{array}$ & $\begin{array}{l}\text { 'based on } \\
\text { Martensson } \\
(2000)\end{array}$ \\
\hline $\begin{array}{l}\text { Robinson } \\
\text { et al. } \\
\text { (2001) } \\
\text { IMPaKT }\end{array}$ & $\begin{array}{l}\text { Define } \\
\text { Business Goals } \\
\text { Identify } \\
\text { business \& } \\
\text { improvement } \\
\text { measures }\end{array}$ & $\begin{array}{l}\text { Assess } \\
\text { Implic'ns for } \\
\text { Orgn K-Base } \\
\text { Indentify } \\
\text { existing K } \\
\text { Determin K gap } \\
\text { Develop KM } \\
\text { initiatives } \\
\end{array}$ & $\begin{array}{l}\text { Assess Impact } \\
\text { Assess results } \\
\text { product } \\
\text { Asses } \\
\text { performance }\end{array}$ & & \\
\hline $\begin{array}{l}\text { Aust Std } \\
\text { HB275- } \\
2001\end{array}$ & $\begin{array}{l}\text { Knowledge } \\
\text { Alignment } \\
\text { Context } \\
\text { Analysis } \\
\text { Planning }\end{array}$ & $\begin{array}{l}\text { Knowledge } \\
\text { Processes } \\
\text { Sharing } \\
\text { Acquisition } \\
\text { Creating }\end{array}$ & $\begin{array}{l}\text { Knowledge } \\
\text { Foundations } \\
\text { Culture } \\
\text { Technology } \\
\text { Sustaining } \\
\text { Systems }\end{array}$ & & \\
\hline
\end{tabular}

Table 1. Comparison of KM Frameworks

(Adapted from Tyndale (2001) p 668)

Ribiere and Chou (2001) do discuss risk management as background to their discussion of $\mathrm{KM}$ in the banking environment (refer Figure 2) but do so by suggesting that $\mathrm{KM}$ could help the risk management process via the use of knowledge maps rather than the $\mathrm{KM}$ using risk management as a technique. However, they do mention that trust and confidence are essential elements in banking and that by implementing $\mathrm{KM}$, banks may be able to strengthen the trust and confidence factor that results from solid customer relationships, and use $\mathrm{KM}$ as a strategy for customer retention and acquisition. The problem is that trust may be broken quite easily in $\mathrm{KM}$ systems that are not well protected and this may lead to lack of confidence and customer loss - hence the importance of risk management for KM. While identifying where KM can assist risk management Ribiere and Chou (2001) miss the opportunity to see the benefits that risk management might offer to KM.

Standards Australia provides a Framework for $\mathrm{KM}$ and refers to risk management in relation to Establishing Priorities and Sustaining Systems for Knowledge Management (Standards Australia International, HB275-2001, 2001: refer section 3.2.1b p13-15; section 5.3.1 p47; and Appendix C p5354). Standards Australia sees risk areas involving:

- Project

- Strategy (Alignment) 
- Process

- Foundations

However, risk management is broader than this and should also refer to identifying risks, security and controls for EBKM infrastructure and systems. The use of the Risk Management Standard AS/NZS4360 (Standards Australia, 1999) should also be considered by the IT governance committee. This risk management process is shown in Figure 3. The IT governance committee needs to appoint persons to carry out this risk management process. We suggest the Chief knowledge Officer of the organization together with the IT internal auditor/security officer are appropriate persons to carry out this task. IT audit standards (ISACF, COBiT 3rd Edition, 2000) and the IT governance framework developed by the IT Governance Institute (ISACF, K-Net, 2001) should also provide guidance in this area.

The KM risk management team should firstly identifying the $\mathrm{KM}$ assets (including personnel, systems, infrastructure and networks, locations) and then identifying risks associated with these assets. The next phase involves identifying existing controls and security measures over these assets and then analysing the risks by determining the likelihood, consequence and level of the risks. The risks are then evaluated and prioritised, and an action plan drawn up to implement the recommendations for additional $\mathrm{KM}$ security and control measures to counter or mitigate the identified KM risks. For some KM risks, management may accept the risk, thereby self-insuring against that risk. During this process it is important to communicate with management and staff involved in $\mathrm{KM}$ about the findings from the risk management process, and solicit from them suggestions for improving $\mathrm{KM}$ security and controls. This process is not just carried out once and then forgotten, but should be monitored and reviewed on a continuing basis by the KM governance committee. 


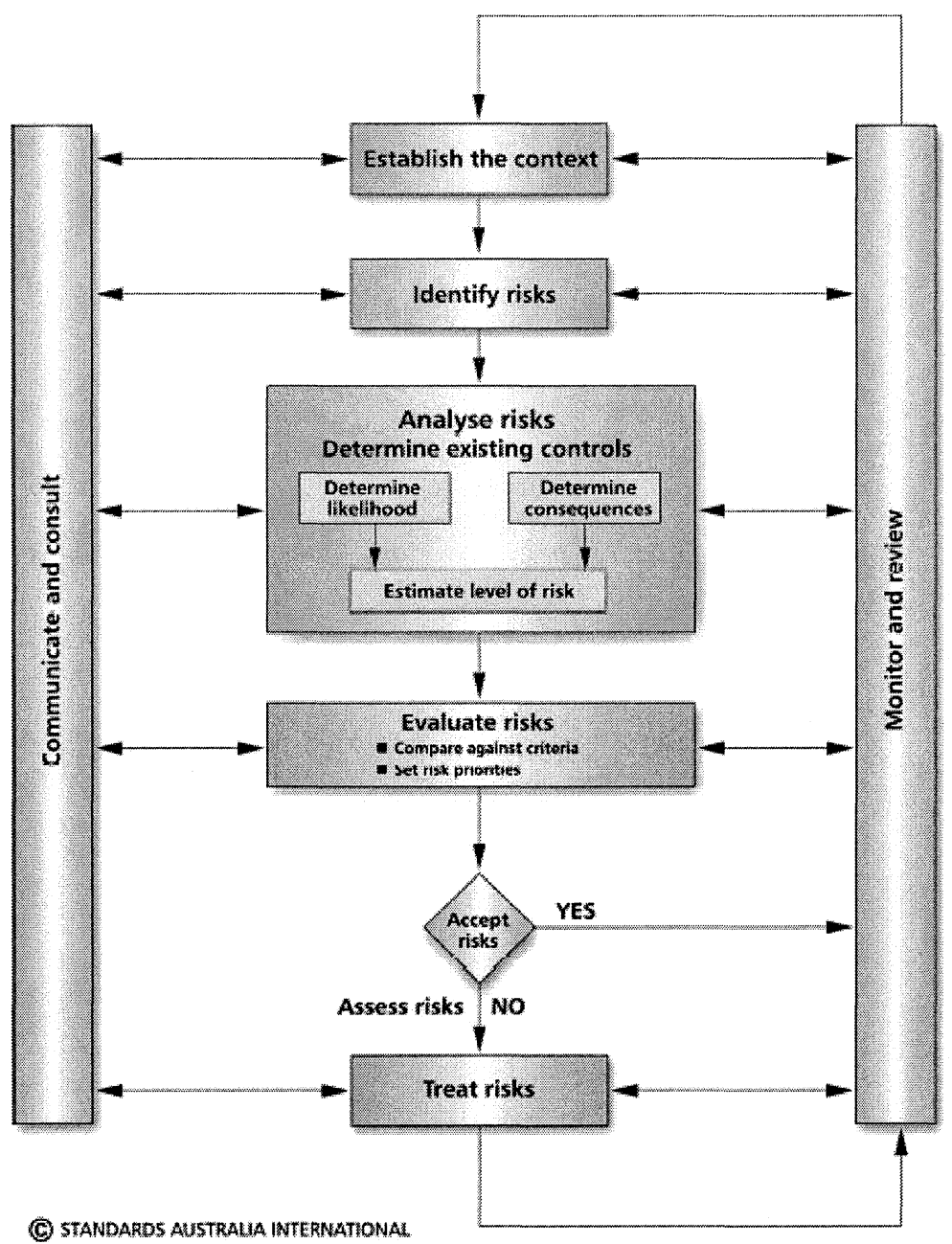

Figure 3. The Risk Management Process

Source: Standards Australia International, 2001, p14

Details of EBKM security and control mechanisms will be covered later in the paper.

The IT governance committee will also need to consider which KM technologies will be employed throughout the organization. EBKM Technologies include:

- retrieval engines,

- content management,

- document and records management, 
- learning systems,

- automatic classification systems - neural networks, linguistic or semantic processing systems,

- intelligent technologies - AI, regression \& correction, expert systems, case-based reasoning, data and text mining, rule-based systems, and

- archiving.

- Each of these technologies has their own risks and associated security and controls mechanisms. However, these technologies need to be considered in light of a knowledge management framework and are just one part of the knowledge foundations required to support the knowledge processes within an organization. To illustrate, standards Australia has formulated a knowledge management framework to guide practitioners setting up knowledge management within their organizations. Such a framework is depicted in Figure 4.

\subsection{Risks within EBKM}

The joint Computer Security Institute and the FBI Computer Crime and Security Survey (CSI, 2001) provide details of the types of risks, security breaches and attacks that organizations are facing in today's turbulent environment. Table 2 provides a selection of risks in the EBKM environment that need to be taken into account by management, security and auditor personnel - refer Jamieson and Handzic, (2002). 


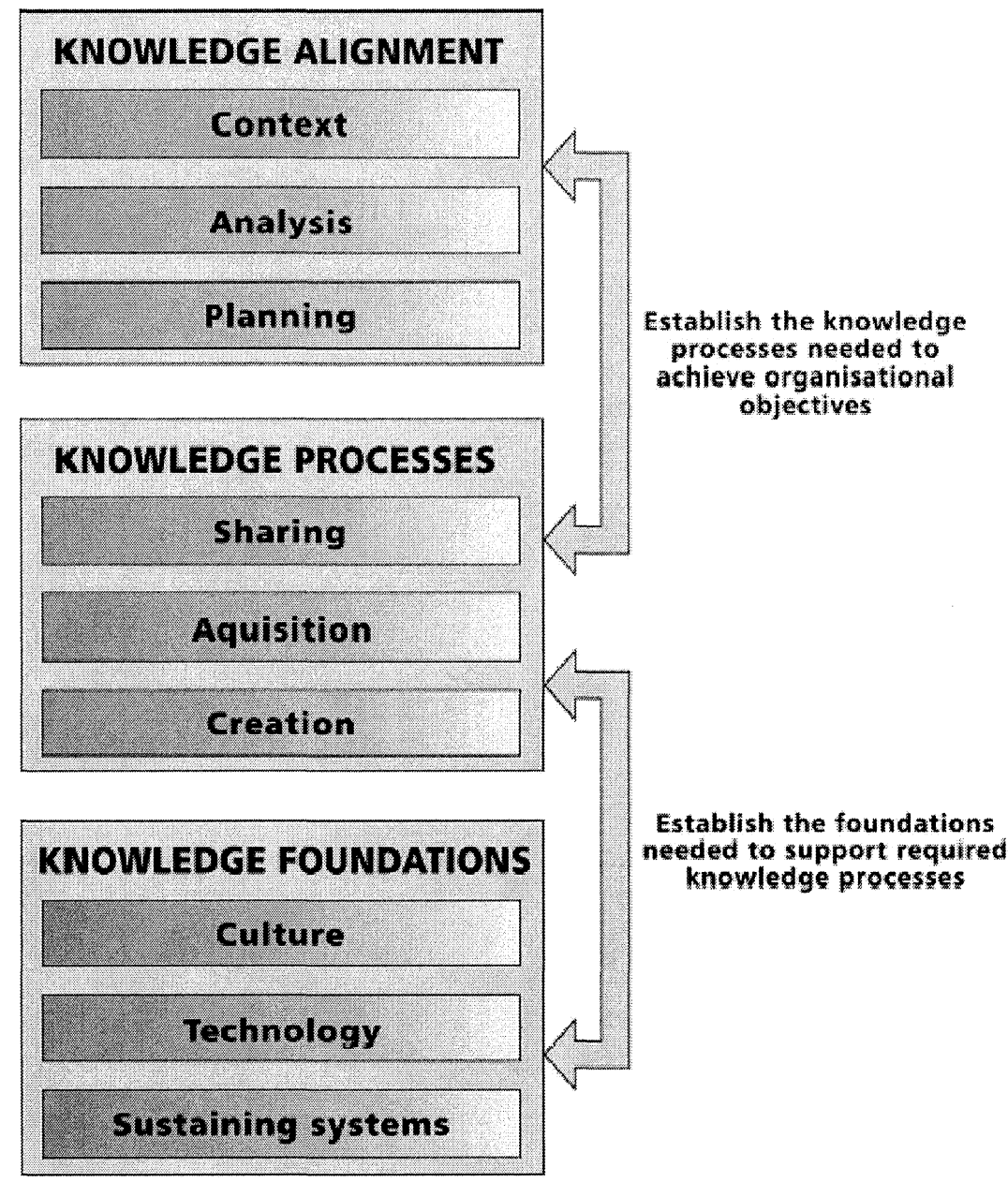

C) STANDARDS AUSTRAKA INTERNATIONAL.

Figure 4. Knowledge Mangement Framework (Standards Australia International, 2001, p5) Risks, Security/Controls, and Privacy 


\begin{tabular}{|c|c|}
\hline \multicolumn{2}{|c|}{ Selection of Risks within EBKM } \\
\hline Strategic/Planning & $\begin{array}{l}\text { mismatch of EBKM strategy to corporate and IT strategies } \\
\text { unidentified or excessive costs especially maintenance and } \\
\text { support } \\
\text { overlooked essential EBKM functionality }\end{array}$ \\
\hline Accidental or intentional & $\begin{array}{l}\text { damage } \\
\text { loss } \\
\text { modification } \\
\text { destruction } \\
\text { use } \\
\text { to/of specialized EBKM or traditional IT hardware used to run } \\
\text { EBKM systems, EBKM software, knowledge repositories, as } \\
\text { well as feeder software and associated data bases. Loss or } \\
\text { incapacitation of key EBKM experts, knowledge engineers, } \\
\text { programmers, or knowledge maintenance personnel, is also of } \\
\text { concern. }\end{array}$ \\
\hline $\begin{array}{l}\text { Fraud and computer } \\
\text { abuse }\end{array}$ & $\begin{array}{l}\text { substitution/deletion of knowledge repositories } \\
\text { obscure placement of forward chaining demons within the } \\
\text { knowledge base if expert systems or knowledge based systems } \\
\text { are part of the EBKM systems } \\
\text { unauthorised access to EBKM systems or EBKM } \\
\text { management/audit trails } \\
\text { modification, deletion or insertion of EBKM information when } \\
\text { passing through a network, communications or other layers of } \\
\text { operating or support software such as data warehousing. This } \\
\text { includes other application software when linked or integrated } \\
\text { with EBKM systems. }\end{array}$ \\
\hline Other Exposures & $\begin{array}{l}\text { inability of imbedded EBKM software to recover/restart } \\
\text { EBKM hardware, infrastructure or software failure - especially } \\
\text { real-time monitoring or imbedded systems } \\
\text { lack of knowledge use histories (audit trails) in hardcopy and/or } \\
\text { magnetic/optical form } \\
\text { inadequate trace facilities in EBKM/KB software for debugging } \\
\text { and EBKM/KB testing } \\
\text { EBKM systems knowledge not based on best expert's } \\
\text { knowledge, reasoning, and explanations } \\
\text { Inadequate control of and access to EBKM repositories } \\
\text { poor quantity or quality of EBKM personnel } \\
\text { poor management, supervision and control of the EBKM } \\
\text { application and repositories if held elsewhere to IT department, } \\
\text { eg. under R \& D } \\
\text { inadequate training and supervision of EBKM personnel } \\
\text { inadequate EBKM hardware/software maintenance } \\
\text { legal liability for reliance on EBKM opinion when that opinion } \\
\text { caused loss of life, damage or monetary loss } \\
\text { inadequate EBKM documentation of tools, environment and } \\
\text { applications }\end{array}$ \\
\hline
\end{tabular}


As well as these risks EBKM management should be cognisant of the security and control considerations applicable to the EBKM environment.

\subsection{Security and Controls for EBKM}

Holsapple and Joshi (2000) provide an investigation of factors that influence the management of knowledge in organizations. One of the managerial influences on EBKM is control which involves two critical issues of protection and quality of the knowledge resources. They believe that the protection of knowledge resources from “... loss, obsolescence, unauthorized exposure, unauthorized modification, and erroneous assimilation is crucial for the effective management of knowledge"(Holsapple and Joshi, 2000, p240). They argue that management needs to consider knowledge validity (accuracy, consistency and certainty) and knowledge utility (clarity, meaning, relevance and importance) when establishing sufficient controls to govern knowledge quality. The security and controls discussed in this paper are concerned with knowledge validity. Considerations associated with operational EBKM systems are presented below and are summarized in Table 3 - refer Jamieson and Handzic, (2002).

\begin{tabular}{|l|l|}
\hline Selection of Security and Controls in the EBKM Environment \\
\hline EBKM Hardware : & Sensitive knowledge access: \\
key locked equipment \\
restricted/controlled boot up procedures \\
biometric access controls \\
encryption provisions \\
Up-to-date documentation \\
Regular audits of EBKM equipment \\
Logging and follow-up of all reported faults \\
EBKM back-up: \\
strategy \\
equipment \\
EBKM maintenance: \\
diagnostic aids \\
documentation \\
EBKM environmental considerations: \\
uninterrupted power supplies or voltage regulators \\
air conditioners \\
physical protection barriers to restrict physical access \\
Security infrastructure
\end{tabular}




\begin{tabular}{|c|c|}
\hline EBKM Software & $\begin{array}{l}\text { Automated procedures for EBKM access control } \\
\text { Valid software license agreements } \\
\text { Up-to-date documentation } \\
\text { EBKM software integrity checks } \\
\text { Appropriate EBKM maintenance strategy } \\
\text { EBKM software upgrade controls } \\
\text { Logging and follow-up of all reported software faults } \\
\text { EBKM repository encryption } \\
\text { EBKM explanation facilities if using expert systems or KBS: } \\
\text { HOW facilities } \\
\text { WHY facilities } \\
\text { Help facilities } \\
\text { EBKM repository integrity checking } \\
\text { Restricted screen/report output and knowledge document delivery } \\
\text { Separate development and run time versions } \\
\text { Graphical layouts of EBKM repository } \\
\text { Cross reference listings } \\
\text { Knowledge dictionary or thesaurus maintenance access and } \\
\text { controls } \\
\text { Knowledge use trace facilities } \\
\text { Knowledge use or consultation case history maintenance if KBS } \\
\text { Audit trail logging of all activity } \\
\text { Certified by major consulting/accounting firm }\end{array}$ \\
\hline EBKM Development & $\begin{array}{l}\text { EBKM development methodology followed } \\
\text { Separate EBKM development from production EBKM } \\
\text { Appropriate design documentation } \\
\text { Validation and testing of EBKM systems } \\
\text { Quality assurance/control review } \\
\text { Auditor involvement in EBKM development reviews } \\
\text { Separate development and production EBKM source libraries } \\
\text { Separate development and run time versions of EBKM software }\end{array}$ \\
\hline EBKM Applications & $\begin{array}{l}\text { Systems access security (password as minimum) \& strong } \\
\text { authentication } \\
\text { Smart Cards } \\
\text { Secure Client (IPSec) } \\
\text { Digital Certificates } \\
\text { Correct option setting for run time versions } \\
\text { Edit facilities for data input } \\
\text { Knowledge repositories/KB encryption } \\
\text { Reasonableness checks } \\
\text { Output review by competent EBKM personnel } \\
\text { Hardcopy or magnetic/optical collection of case histories } \\
\text { Management/audit review of audit trails } \\
\text { Good application documentation } \\
\text { Unauthorised copying protection } \\
\text { Back-up and recovery }\end{array}$ \\
\hline
\end{tabular}




\begin{tabular}{|c|c|}
\hline $\begin{array}{l}\text { EBKM Network } \\
\text { Controls }\end{array}$ & $\begin{array}{l}\text { Internet, Extranet or Intranet access controls } \\
\text { Virtual Private networks (VPN's) - site to site } \\
\text { VPN Gateway } \\
\text { Transmission encryption of Knowledge in transit } \\
\text { Public Key Infrastructure (PKI) } \\
\text { Dedicated connections } \\
\text { Firewalls }\end{array}$ \\
\hline $\begin{array}{l}\text { EBKM Human } \\
\text { Resources }\end{array}$ & $\begin{array}{l}\text { Management commitment to EBKM strategy } \\
\text { Assign responsibility for: } \\
\text { EBKM development } \\
\text { EBKM production operations } \\
\text { EBKM disaster planning } \\
\text { Adequate training of EBKM personnel } \\
\text { Supervision and management of EBKM personnel } \\
\text { EBKM Information Centre } \\
\text { Segregation of duties } \\
\text { Mandatory vacations } \\
\text { Personnel security checks } \\
\text { Maintenance supplier vetting }\end{array}$ \\
\hline
\end{tabular}

Table 3. Selection of Security and Controls in the EBKM Environment

An example of security and control concerns is provided in the following section in relation to knowledge repositories.

\subsection{Security and Control Concerns with Knowledge Repositories}

There are a number problems associated with knowledge repositories. One of problems involves where the knowledge repositories are located and who is responsible for them and their security. If the knowledge repositories are controlled in the same way as corporate databases, then they may fall under the security that is given to all other major IT systems. However, if the knowledge repositories are located within an end user environment on a knowledge server then these systems may not be well controlled. As a result, knowledge management systems may have no systems access security, inadequate monitoring, and lack of adequate backup and recovery procedures and facilities. If this is the case then management may need to review the security over these knowledge management systems and apply the same procedures as they would over their corporate IT systems. With knowledge repositories we need to ask questions as to who is responsible for placing documents within the repository, how is access to these documents controlled, and who is responsible for the disposal of the documents for disposal. 
Some organisations have setup knowledge centres within the various divisions of their organisation. These knowledge centres are responsible for the addition, maintenance and review of documents placed within the knowledge repositories. These knowledge centres should also be responsible for the security and accuracy of information and knowledge that is placed within the repositories. Personnel in these knowledge centres should also be responsible for the setting up and maintenance of the knowledge dictionary or thesaurus for the organisation. The knowledge dictionary is very important to the organisation as it holds the key to accessing the many documents held within knowledge repositories. Knowledge held in documents within the knowledge repository is indexed and accessed by the terms within the knowledge dictionary. Therefore, protection over the knowledge dictionary is equally as vital as security over knowledge repositories. A person having access to the knowledge dictionary in a covert or incompetent manner may in fact intentionally or accidentally destroy or corrupt key terms within the knowledge dictionary. They may in fact destroy the whole knowledge dictionary or substitute another in its place. Rebuilding of the knowledge dictionary may in fact take person days of effort and in fact may be impossible to reconstruct, thereby causing the organisation significant losses due to the inability to access documents within the knowledge repositories.

Another concern is with the knowledge held within the knowledge repositories. Firstly, how are documents held within the knowledge repositories, are they encrypted or held in a clear text form? Secondly, are all documents held in a form that cannot be altered, or are these documents in an open form so that many people within the organisation may have assess to substitute, modify or delete them. If the documents are held in an Acrobat PDF form, then document security features may be enabled that provides protection on features such as content accessibility, print, change, extract or copy, altering author comments and fields, and document assembly. Adobe Acrobat also provides password protection and encryption over the document and over the documents security features.

Three important concerns relating to security include confidentiality, integrity, and availability (IT Governance Institute, 2001). Confidentiality involves ensuring that the knowledge held remains confidential and is only used for the purposes to which that knowledge was collected. Confidentiality also implies that there may be degrees of confidentiality associated with a document. For example there may be three levels of confidentiality namely, open access, commercially in confidence, for management eyes only. These levels of confidentiality need to be carefully thought through by an organisation so that they come up with their own method of grading 
information and then allowing that information to be used, so that only authorised personnel within the organisation that have appropriate clearance will have access to the knowledge held at that level. Confidentiality relates closely to privacy concerns discussed in a later section.

Integrity is an issue fact may be overlooked by those responsible for the knowledge management system. Integrity of relates to be knowledge being held in the knowledge repositories current and correct overtime. Integrity implies that the knowledge in the knowledge repository will remain current and correct or accurate, overtime. This embodies the ideas of accuracy of the knowledge and also the currency of knowledge. In the knowledge management system a lack of accuracy or currency of knowledge held may involve the organisation in serious loss, damage to reputation, or severe financial exposure as a result of decisions made on the basis of that knowledge. Thus, it is important to audit the knowledge held within the knowledge repositories to ensure that that knowledge is current and correct overtime. Integrity also relates to the security of the knowledge held. If an unauthorised person has access to knowledge held within a document then they may substitute, modify or delete knowledge and therefore compromised the accuracy and integrity of the knowledge incorporated within the document.

Monitoring of knowledge use is also an important concern. It is important for an organisation to be able to track who has access the knowledge documents in the repository, when that document was accessed, what was done to the document during the access, and if tracked, what use was made of the knowledge. Many knowledge management systems may not have the auditing and monitoring facilities to allow this to be tracked and captured. Others may have the facility within the knowledge management system but this facility may not have been enabled. In other cases the logs from the monitoring system may not be kept for an appropriate length of time.

Availability of the knowledge repository is also an issue that needs to be addressed. It is of no use to have a knowledge repository that is unavailable to knowledge workers around the globe. This may arise through some unfortunate incident which may have destroyed the knowledge repository or prevented access to this repository. Examples may include an act of cyber terrorism or actual terrorism, accidental mishaps leading to the deletion of key knowledge repositories, or an attack that may render communication lines to the repository inoperative.

Availability requires that an organisation's knowledge infrastructure including communication lines, knowledge servers and knowledge systems are all operational and are securely protected from penetration. Should such a disaster occur, it is important that a fallback facility is pre-arranged so that 
the organisation may keep operating as usual after a disaster occurs, by switching to those fallback facilities. It is a must that key knowledge systems and associated knowledge repositories are backed up and held securely offsite. Many organisations are using electronic vaulting as one of their backup and recovery strategies.

\subsection{Privacy}

Zannes (2000) discusses the conflicts between security and knowledge sharing. In the act of knowledge sharing we may unwittingly compromise the privacy of the knowledge in the repositories. So, privacy is an important issue to address when discussing knowledge repositories. In many countries there are privacy legislation for both public and private sectors. Privacy legislation usually requires that an organisation informs all persons, from whom the organisation is soliciting knowledge or information which is going to end in a knowledge repository, of certain key privacy tenets affecting how the information or knowledge solicited from them will be used and retained in the knowledge repository. Contributors need to be informed of what information or knowledge is being captured in the first place and then informed as the use for which that information or knowledge will be used in the future. It is then the organisation's responsibility to monitor who has access to that knowledge, who maintains the knowledge, and how that knowledge is used a within the organisation. If there is open access to knowledge documents within the knowledge repository, this may seriously compromised centres criteria of privacy legislation within the organisation. For example, even when an organisation is capturing knowledge from persons using the World Wide Web then they may need to have a privacy statement on the Web for their knowledge management system that informs the users /contributors of the privacy conditions that will apply to knowledge being given. Breaches of privacy in EBKM systems may cause lack of trust by customers/contributors and even leave the organization open to legal liability.

Many countries either have privacy legislation or are currently implementing legislation. In Australia, new national privacy laws came into effect on December 21, 2001 under the Privacy Amendment (Private Sector) Act 2000. The privacy legislation is based on 10 key National Privacy Principles (NPPs) (Privacy Commissioner, 2001):

1. Collection - only collect information relevant to your organisation by fair means and not in an unreasonable intrusive way. For EBKM, this means having a clear, coherent and specific privacy policy stating who your 
organisation is, what knowledge your are collecting, who will see the knowledge, why you need the knowledge and what will happen if you don't have the knowledge.

2. Use and disclosure - you cannot disclose personal information unless it is for a specific need and customers/contributors would reasonably expect you to do so. Knowledge users/contributors are trusting your organisation when they give you personal information, and its in your organisation's best interest not to abuse that trust in any way. Make sure that you run any questionable ideas past your organisation's privacy officer, legal representative or privacy consultant.

3. Data quality - make sure the personal information you collect, use or disclose is accurate, complete and up-to-date. For EBKM systems, this involves ensuring that the personal information or knowledge captured in knowledge repositories remains current and correct. This may involve offering a Web self-service portal to the knowledge repository so that customers/contributors can notify you of any changes or make changes themselves to their personal information or knowledge stored in the knowledge repository.

4. Data security - an organisation needs to take reasonable steps to protect personal information from misuse and loss from unauthorised access, modification or disclosure. There is need to destroy or eliminate identifying details from information you no longer need for a specific purpose. For EBKM, this means implementing appropriate security measures that both protect the personal data and knowledge stored in knowledge repositories (e.g. by encryption) and prevent unauthorised access to the repositories and/or use of that knowledge (e.g. by authentication, systems access control, and activity logging).

5. Openness - an organisation must document it's personal information management policy and make this policy available to anyone who asks for it. For EBKM, this entails publishing the EBKM personal information management policy on a web page prior to customers/users entering the EBKM site, and includes links to your privacy policy on your web site. Also consider auditing and certification of your privacy policies through such organisation's as the Australian Privacy Compliance Centre (www.privacycompliance.org), and eTick administrator of the Australian Privacy Seal Audit and Certification (APSAC) program.

6. Access and correction - organisations are to let customers see information held on them and must be able to correct any incorrect information held. For EBKM, this involves either an online self-service portal or a K-Centre providing procedures for customers/contributors to update incorrect or changed information/knowledge via email, fax or call Centre. 
7. Identifiers -organisations cannot use the same identification number or code that another organisation has assigned to a particular customer. This is in order to prevent aggregation of customer or client data from multiple sources. For EBKM, this means that the organisation should develop its own process for identifying customers/contributors and ensure that they do not communicate customer/contributors identifiers when sharing this information with other organisations including multiple divisions of a company.

8. Anonymity - where practicable individuals must have the option of not identifying themselves when entering into transactions with an organisation. For EBKM, this entails that we do not demand personal information just to allow customers/contributors to enter our knowledge repositories site. The EBKM systems meet built with the basic level functionality that is available to anybody, and the second tier offering extra value add-ons if a customer/contributor offers you more information about themselves.

9. Transborder data flows - organisations should not transfer information out of Australia unless the recipient is in a jurisdiction where privacy is up to the NPP standards and the recipient is likely to uphold customer/contributor's privacy. Organisations should get approval for these transfers wherever possible. For EBKM, this means great care should be taken with whom knowledge and personal information is to be communicated. Compromising customers/contributors privacy may seriously damage organisation's reputation and may even lead to legal liability.

10. Sensitive information - do not collect sensitive information about people unless they have provided authorisation, or would authorise it but cannot, or the organisation needs the information to benefit public health or safety. Although the law does not define 'sensitive', this principle is intended to protect medical records and other health-care related information. So for EBKM systems holding personal information and knowledge about customers'/contributors' medical or health records, the organisation should seek legal advice before implementing knowledge systems dealing with this type of information and knowledge.

Many knowledge management systems interact or form a key component of customer relation management (CRM) systems. The privacy principles and implications outlined above should be seriously taken into account by $\mathrm{KM}$ when developing and implementing these systems. 


\section{RESEARCH IN PROGRESS}

The research methodology consists of the following phases: literature review; survey of risk management risk, security and controls, and privacy within organisations, followed by detailed case studies with global organisations having mature EBKM in order to study their approach to risk management of EBKM. The research framework set out above help to frame the research by setting out the risks, security and controls which should be relevant in a EBKM environment, the survey discussed below will assist in the verification of these risks, security and controls providing a breadth of coverage. This will be followed by a series of case studies to gain depth of knowledge and verification in this area.

To date a survey is under preparation which will identify risk management practices for EBKM within organisations. The survey will help to identify a ranked importance set of EBKM risks, security and controls measures. This should provide guidance to organisations when undertaking knowledge management governance, as well as providing a framework for management implementing EBKM security and controls within their organisations. Privacy is an increasing concern for organisations and the survey should help to provide guidance to organisations as to the impacts of privacy on EBKM. The survey will be run online using Australian Chief Knowledge Officers or their designates as the participants in the study.

Currently the first case study is underway with Schlumberger, a global organisation, which is a gas and oil exploration company operating within 150 countries, provide global knowledge management for their organization. This organisation needs a global infrastructure to enable knowledge management by both intranets within the company and extranets to link their customers and divisions to worldwide knowledge repositories. A global secure infrastructure is needed to guarantee bandwidth and some of the security technologies employed include VPN (virtual private network), PKI (public key infrastructure), and encryption. The results of this and other case studies will provide best practice guidelines for EBKM management in the areas of risk management, security and privacy.

\section{CONCLUSION}

This paper has presented the challenge of appropriate security and control of the knowledge management systems. The literature review has revealed a major problem that risk management is not explicitly factored into the current EBKM development frameworks and models presented in the literature. The only framework that mentions risk management is from 
Standards Australia (2001), but even this framework does not provide any guidance as to how this should be implemented. The development of a more detailed risk and security framework in this author's research should act as a catalyst in the EBKM area to ensure appropriate governance of EBKM systems under development and in operation. Research in this area as to the validation and importance of appropriate risks, security and controls for EBKM and their incorporation into a research framework, should then provide guidance to EBKM management in the security and control of the EBKM environment. Results from case study analysis should also provide best practice guidelines for EBKM management. Neglect of these concerns may lead an organisation being exposed to destruction of key EBKM resources, unwanted litigation and adverse publicity. By considering EBKM governance and the use of appropriate risk management methodologies and techniques, the CKO and his team responsible for knowledge management should be able to put in place appropriate security and control measures over the knowledge management environment, systems and repositories to counter these risks.

\section{REFERENCES}

Alavi M. and Leidner D.E. (2001), Knowledge Management and Knowledge Management Systems: Conceptual Foundations and Research Issues, MIS Quarterly, 25/1, March, 107136.

Angus, J., Patel, J. \& J. Harty (1998), Managing Knowledge, Addison Wesley Longman Publishing Co.

Capshaw, S. (2000); “The knowledge audit”, Knowledge Management, May,, 25-26.

CSI (2001), "2001CSI/FBI Computer Crime and Security Survey”, Computer Security Issues and Trends, Computer Security Institute, 5, 1, Spring, 1-18.

Debenham, J.K. \& J. Clark (1995), "The Knowledge Audit", Robotics and ComputerIntegrated Manufacturing, Elsevier Science, 11, 3, 201-211.

Denning, S., World Bank in Doyle, S. (2001), "A Little Knowledge Can be a Dangerous Thing: Issues in Knowledge Management", Proceedings from Oceania CACS 2001, Information Systems Audit and Control Association, Canberra, ACT, 23-26 September.

Doyle, S. (2001), "A Little Knowledge Can be a Dangerous Thing: Issues in Knowledge Management", Proceedings from Oceania CACS 2001, Information Systems Audit and Control Association, Canberra, ACT, 23-26 September.

Dolye, S. (1997), “Securing Electronic Documents”, KPMG Global Knowledge Management Respository.

Earle, M. (2001), Knowledge Management Strategies: Toward a Taxonomy, Journal of Management Information Systems, Vol 18, No 1, 215-233.

Handzic, M. \& H. Hasan (2002), Integrated Km Frameworks, in Handzic, M. \& H. Hasan Studies in Knowledge Management, forthcoming. 
Handzic, M. and R. Jamieson (2001), "A Knowledge Management Research Framework for Electronic Commerce", Proceedings of the IFIP TC8 Working Conference on Electronic Commerce, Salzburg, Austria, 22-23 June, 2001.

Handzic M. (2001) Knowledge Management: A Research Framework, in Proceedings of the 2nd European Conference on Knowledge Management, Bled, Slovenia, 8-9 November.

Holsapple C. W. \& M. Singh (2000), "Electronic Commerce: From a Definitional Taxonomy Towards a Knowledge Management View", Journal of Organisational Computing and Electronic Commerce, Vol 10, No 3, 149-170.

Holsapple, C. W. \& K. D. Joshi (2000), “An Investigation of Factors that Influence the Management of Knowledge in Organizations", Journal of Strategic Information Systems, 9, 2-3, 235-261.

Horricks, B. \& J. Moss (1993), Practical Data Administration, Hertfordshire, UK: PrenticeHall.

ISACF (2000), COBIT: Control Objectives for Information and Related Technology, $3^{\text {rd }}$ Edition, Rolling Meadows, IL: IT Governance Institute and Information Systems Audit and Control Foundation.

ISACF (2001), K-Net, Global Knowledge Network for IT Governance, Control and Assurance, Rolling Meadows, IL: IT Governance Institute and Information Systems Audit and Control Foundation, URL = www.isaca.org $/$ knet.

IT Governance Institute (2001), Information Security Governance: Guidance for Boards of Directors and Executive Management, Rolling Meadows, IL: Information Audit and Control Foundation.

Jackson, C. (1999), Process to Product - Creating Tools for Knowledge Management, Conference in Lisbon Portugal.

Jamieson, R. (1991), Auditing Expert Systems. Research Monograph No 3, Carol Stream, Illinois: EDP Auditors Foundation Inc.

Jamieson R and Handzic, M. (2002): A Framework for the Security, Control and Assurance of Knowledge Management Systems forthcoming in Holsapple, C., Handbook on Knowledge Management, Springer-Verlag, Heidelberg (in press).

Joseph, E.C (1999), "Knowledge Management Audits", Proceedings of the International Conference on Technology and Innovation Management, PICMET, 1, p442.

Kalakota, R. and A. B. Whinston (1996), Frontiers of Electronic Commerce. Reading, MA: Addison-Wesley.

Malhotra, Y. (2002), Why Knowledge management Systems Fail?: Enablers and Constraints of Knowledge Management in Human Enterprises, forthcoming in Holsapple, C., Handbook on Knowledge Management, Springer-Verlag, Heidelberg (in press).

Martin, E., Ferguson, D., Lewis, S., Lynch, N. \& S. Doyle (1996), Data Administration Practice in Federal Government Organisations: A Pilot Study, University of Canberra (unpublished).

McAdam, R. \& S. McCreedy (1999), A Critical Review of Knowledge Management Models, The Learning Organisation, Vol6 No 3, 91-100.

Nonaka, I (1998), The Knowledge-Creating Company", in Harvard Business Review on Knowledge Management. Harvard Business School Press, Boston.

Nonaka, I. (1991), The Knowledge Creating Company", Harvard Business Review, Vol 69, No 6, 96-104.Privacy Commissioner (2000), National Privacy Principles- Extracted from the Privacy Amendment (Private Sector) Act 2000, URL = www.privacy.gov.au/publications /npps01.html.

Ramos, D. (2001), “The Auditor's Role in IT Governance”, Information Systems Control Journal, 5, 23-24. 
Ribiere, V. \& C Chou (2001), Knowledge Management in the Banking Industry, in Proceedings of the 2nd European Conference on Knowledge Management, Bled, Slovenia, 8-9 November.

Robinson, H. S., Carrillo, P., Anum,ba, C. J. \& A. M. Al-Ghassani (2001), A Conceptual Framework for Improving Management Performance through Knowledge Transformation, in Proceedings of the 2nd European Conference on Knowledge Management, Bled, Slovenia, 8-9 November.

Ruggles, R. (1997), Knowledge Management Tools, Oxford, Butterworth-Heinermann.

Standards Australia (2001), HB275-2001, Knowledge Management: A Framework for Success in the Knowledge Era., Sydney, NSW: Standards Australia International Limited.

Standards Australia (1999), AS/NZS 4360:1999 Risk Management. Sydney, NSW: Standards Australia International Limited.

Standards Australia (1996), AS4309 Records Management, Sydney, NSW: Standards Australia International Limited.

Tyndale, P. (2001), The Organisational Knowledge Development Life Cycle: From Knowledge Creation to Knowledge Application, Proceedings of the 2nd European Conference on Knowledge Management, Bled, Slovenia, 8-9 November.

Wong K., Ng, B., Cerpa, N. \& Jamieson R. (2000), "An Online Audit Review System for Electronic Commerce", Proceedings of the 13th Bled Electronic Commerce Conference 2000, Bled, Slovenia, June 20-23.

Wright M. (2001), Risk Based Auditing and Risk Management, ISACA Technical Seminar, Information Systems Audit and Control Association, 8 November, Sydney.

Zannes, E. (2000), Knowledge Management in Industry and Government: The Conflict between Security and Knowledge Sharing, Proceedings IEEE 34th Annual International Carnahan Conference on Security Technology, 2000. 